\title{
Islam, Individual Freedom, and the Pandemic: Reflections of a Muslim American Woman Living in the Middle East
}

\begin{abstract}
Khabirah Yahya*
We hold these truths to be self-evident, that all men are created equal, that they are endowed by their creator with certain unalienable rights, and among these are life, liberty and the pursuit of happiness.
\end{abstract}

- The Declaration of Independence, 1776

The Fourth of July holiday has just passed, which makes me think about the idea of individual freedom and how it means different things in the US than it does in the Middle East, where I currently reside. In the first few months of 2020, not only was the world exposed to the horrors of the current COVID-19 pandemic and the ensuing economic slowdown, but also to the bizarre reaction of much of the US to this contagion. As coronavirus diagnoses and deaths began to increase within the country during late February and into early March, a clear and very volatile divide in terms of how Americans responded to the pandemic also started to become apparent. On one side, some began to alert all of their friends on social media to the menace and call for lockdowns and quarantines in the interest of the communal public health. Many others, however, were vehemently against such measures and even stated that the coronavirus was a complete "hoax" and a "scam" being perpetrated by the left and Democrats to ensure the president's defeat in November. Some even went so far as to claim that Bill Gates had hatched this "scheme" in a bid for global domination.

The US government's initial response to the threat was neither immediate nor robust. Consequently, the infection spread rapidly. Not surprisingly, when domestic coronavirus cases began to increase exponentially in early March, numerous cities and states implemented and enforced lockdowns and quarantines. While many Americans were grateful for these governmental measures, the reaction of others was nothing less than astounding. Significant numbers of Americans began asserting that their constitutional rights as citizens were being infringed upon and started demanding the economy's immediate reopening.

\footnotetext{
* Khabirah Yahya is an International Educational Consultant and Visiting Faculty at the Islamic Seminary of America.
} 
At this point, I started reflecting on the meaning of freedom in America. Within a couple of weeks, the situation grew stranger when masses of people, many of them armed and waving the Confederate flag, descended upon state capitols, demanding that their governor reopen the state at once in the name of freedom. Is this what the famous philosopher John Locke (1632-1704) meant when he said that every human being has the right to individual freedom? According to him, the government has a responsibility to protect an individual's life, liberty, and property because they are all basic human rights. However, in order for that to work, people have to give up some individual freedom in order to serve the common good.

Frequently, the documents that these protesters referred to were the US Constitution and the Declaration of Independence, upon which they based their claim that the state-imposed lockdowns directly violated their fundamental liberties. They often acknowledged the virus' dangers and reality, but asserted that they had the right to choose whether to risk infection or not. It is clear from my reading of online US newspapers and watching American streaming news footage of many of these protests that these people truly believed in what they were saying and were aghast that their civil liberties were being "trampled upon" in the interest of public health.

As a resident of first one and then another Arab Middle Eastern country for more than a decade, all of this was very strange to me. I saw a very different reaction from both Arab governments and their people. As soon as COVID-19 cases began to appear, governments immediately shut down schools, imposed curfews, mandated the wearing of gloves and masks in public, suspended activities at all houses of worship, and imposed strict fines on anyone who refused to abide by these conditions (Staff, 2020). I will never forget the first time I heard the distress adhān echoing throughout my neighborhood's streets in response to the spread of COVID-19. Instead of the usual "come to prayer," I heard "pray in your homes." While feeling sad about the mosques' closing, I also felt relief and a sense of safety because I knew that the government was taking precautions to keep all of us safe. In the Arab Middle East, I have never heard anyone bring up the fact that they thought these measures were "tyrannical," "fascist," or "authoritarian," for they well understood that these were necessary measures and sacrifices taken for the overall public good and well-being.

To be sure, generally speaking, the governments of most Arab countries daily place many repressive anti-democratic restrictions on their citizens, and therefore the latter have no inherent expectation of "constitutionally mandated" liberties. Nevertheless, contrasting these two situations provides much food for thought about differing global notions of "liberty." For instance, Islamic teachings on dealing with infectious diseases and afflictions played a major role in how the Muslim-majority Middle Eastern countries responded. We, as Muslims, had al- 
ready been taught through verified Prophetic reports that we should neither enter nor exit geographical areas in which plagues existed so as to contain their spread, and to stay at home instead of going to the places of worship to prevent an infection's spread.

According to Sahīh al-Bukhārī hadith 5396 (1997), Sa'd reported: "The Prophet (peace and blessings be upon him) said, 'If you hear of a plague in a land, then do not go into it. If it happens in land where you are, then do not go out of it." Not only are we instructed to contain the contagion, but we are given glad tidings of a reward from Allah if we patiently quarantine ourselves and remain hopeful. According to Sahịh al-Bukhārī hadith 5402 (1997), A'ishah (may Allah be pleased with her) reported that she asked the Messenger of Allah (peace and blessings be upon him) about the plague. He told her that it was a torment that Allah would send upon whom He willed. Allah then made it a mercy for the believers so that anyone in an afflicted area who stays therein, patiently hoping for His reward and believing that nothing will befall him except what Allah has foreordained for him, will receive a reward similar to that of a martyr. All of these instructions parallel the modern-day concepts of isolation and quarantine.

In the US, all of the protests against COVID-19 precautions, as well as their backing by several federal government leaders, clearly affected many governors and mayors. Even though it was quite clear that by the beginning of April 2020 the pandemic was not slowing down, many of them simply allowed the stay-inplace orders to expire (Wilson, 2020), disregarding the continued warnings of many public health experts that the coronavirus was still present and posed a looming, major existential threat. Nevertheless, large numbers of Americans, thrilled with their freedom, began having parties, going to packed restaurants and bars, and crowding beaches and parks. As a result, the country saw a recordbreaking uptick in new infections and deaths during July 2020 (as I am writing this reflection). Furthermore, there will most likely be another major wave of infections and deaths that may equal or even exceed the first one.

Even though removing the stay-in-place orders was clearly a mistake, most state governmental officials are stating that it is now impossible to "put the genie back in the bottle," as it were, and are refusing to impose any further such orders. Even more appallingly, many of them are calling for public schools to fully reopen in the fall and simply act as though it is "business as usual." This action will almost certainly place millions of children, their family members, and their teachers at risk.

As a resident of the Arab Middle East, watching all of this unfold has led me to seriously wonder if the concept of "liberty" that many Americans embrace is seriously misplaced and a danger to the public welfare. After all, if obtaining "liberty" means having the freedom to make other people sick, to make one's own self ill, and to seriously infect one's family members, how can that truly be called 
"freedom"? While the strict conditions in the region may seem to be anathema to many Americans, the fact remains that Arab countries have, like the UAE, a lower coronavirus-related infection and death rate than does the US. As such, many Arab Middle Easterners have been granted "liberty" from an awful illness, long-term negative health effects, and death. Upon reflection, as most Muslim-majority societies clearly have a far more collectivistic mindset, we tend to think of "freedom" in terms of "freedom for all," meaning that the larger community's wellbeing takes necessary precedence over the individual's self-centered wants and needs.

I concede the existence of many other factors underlying the collective anger toward the lockdowns and quarantines from certain factions of Americans. The fact that the US is highly individualistic also means that there are not enough social or governmental "safety nets" in place to help people who lose their livelihoods due to these quarantines. Therefore, much of this anger may have simply been due to fear that the greater public health might interfere with their personal survival needs. Nevertheless, the last few months have caused me to reflect a great deal upon the idea of freedom and the differences between the United States and Arab Middle Eastern societies. Indeed, while the US constantly brags on the world stage that its citizens have a far higher amount of "individual freedoms" than do other global citizens, it frankly seems to me that this "individual freedom" can sometimes be very dangerous for the public welfare.

\section{References}

Bukhari, Muhammad I. 1997 English Translation of the Meanings of Sahīh alBukhārī Arabic-English. Translated by Muhammad M. Khan. New York: Darus-Salam.

Staff Reporter. 2020. Coronavirus: Full list of updated fines for violating Covid19 measures in the UAE. Retrieved from https://www.khaleejtimes.com/ coronavirus-pandemic/coronavirus-full-list-of-updated-fines-for-violatingcovid-19-measures-in-uae--1.

Wilson, J. 2020. US lockdown protests may have spread virus widely, cellphone data suggests. Retrieved from https://www.theguardian.com/us-news/2020/ may/18/lockdown-protests-spread-coronavirus-cellphone-data. 